\title{
SCREENING SLC2A1 GENE FOR SEQUENCE AND COPY NUMBER VARIATIONS ASSOCIATED WITH GLUT-1 DEFICIENCY SYNDROME
}

\author{
GLUT-1 EKSIKLIĞi SENDROMU ILE ILIŞKILI SLC2A1 GENINDE YER ALAN DIZI VE \\ KOPYA SAYISI VARYASYONLARININ INCELENMESI
}

\author{
Cemre ÖRNEK ERGÜZELOĞLU1,8 (D), Bülent KARA² (D), ilker KARACAN ${ }^{1,3}$ (D), Özkan ÖZDEMiR ${ }^{1,4}$ (D), Yeşim KESiM ${ }^{1,5}$ (D), \\ Nerses BEBEK ${ }^{6}$ (D), Uğur ÖZBEK ${ }^{1,7}$ (D), Sibel Aylin UĞUR işERI ${ }^{1}$ (D)

\begin{abstract}
'Istanbul University, Aziz Sancar Institute of Experimental Medicine, Department of Genetics, Istanbul, Turkey ${ }^{2}$ Kocaeli University, Faculty of Medicine, Department of Pediatric Neurology, Kocaeli, Turkey ${ }^{3}$ Istanbul Medeniyet University, Faculty of Engineering and Natural Sciences, Department of Molecular Biology and Genetics, Istanbul, Turkey

${ }^{4}$ University of Cologne, University Hospital Cologne, Center for Molecular Medicine Cologne CMMC, Cologne, Germany ${ }^{5}$ Oxford Brookes University, Faculty of Health and Life Sciences, Oxford, UK.

${ }^{6}$ Istanbul University, Istanbul Faculty of Medicine, Department of Neurology, Istanbul, Turkey

${ }^{7}$ Mehmet Ali Aydinlar Acibadem University, School of Medicine, Department of Medical Genetics, Istanbul, Turkey

\&Uludag University, Faculty of Medicine, Department of Medical Genetic Bursa, Turkey
\end{abstract}

ORCID IDs of the authors: C.Ö.E. 0000-0002-5932-4259; B.K. 0000-0003-3780-6596; I.K. 0000-0003-3100-0866; Ö.0̈. 0000-0002-2647-6416; Y.K. 0000-0003-4423-2367; N.B. 0000-0002-4749-1471; U.Ö. 0000-0001-7031-3932; S.A.U.i. 0000-0002-5790-6853

Cite this article as: Ornek Erguzeloglu C, Ozdemir O, Kesim Y, Karacan I, Kara B, Bebek N et al. Screening SLC2A1 gene for sequence and copy number variations associated with GLUT-1 deficiency syndrome. J Ist Faculty Med 2020;83(3):177-83.

doi: 10.26650/IUITFD.2019.0064

\section{ABSTRACT}

Objective: Glucose transporter-1 deficiency syndrome (GLUT1DS) is defined as a metabolic encephalopathy that is associated with heterozygous and usually de novo pathogenic variations in the SLC2A1 (solute carrier family2 member1) gene.

Materials and Methods: In this study, all coding exons and neighboring intronic regions of SLC2A1 were Sanger sequenced in 12 patients with clinically suspected GLUT1-DS. For de novo variations revealed after sequencing and segregation analysis, we also performed genome wide Single Nucleotide Polymorphism (SNP) genotyping to confirm parental relatedness with the proband. In patients without any sequence variations, real-time quantitative real-time polymerase chain reaction (qPCR) was applied to determine the presence of any copy number variations (CNV).

Results: Sanger sequencing followed by bioinformatics analysis, segregation in the family and SNP array genotyping revealed two novel and de novo pathogenic variations associated with the GLUT1-DS phenotype in 2 patients. qPCR results were com-

\section{ÖZET}

Amaç: GLUT1 eksikliği sendromu (GLUT-1ES) bebeklik çağında başlayan metabolic bir ensefalopati olarak tanımlanmıştır. Kolaylaştırılmış glikoz taşıyıcısı olan GLUT1'i kodlayan SLC2A1 genindeki de novo patojenik varyasyonlardan kaynaklanır.

Gereç ve Yöntem: Bu çalışma kapsamında, GLUT1-ES klinik şüphesi olan 12 hastada SLC2A1 geninin tüm ekzonları Sanger dizileme metodu ile taranmıştır. De novo varyantların anne baba çocuk üçlüsü açısından uyumluluğu Tek Nükleotid Polimorfizmi (SNP) genotiplemesi ile yapılmıştır. Sanger analizinde herhangi bir değişikliği olmayan hastalarda, gerçek zamanlı kantitatif PZR (Polimeraz Zincir Reaksiyonu) analizi ile kopya sayısı değişimleri incelenmiştir.

Bulgular: Sanger dizileme, biyoinformatik analiz, aile segregasyonu ve SNP genotipleme yaklaşımlarının ardarda uygulanması ile 2 hastada GLUT1-ES fenotipiyle ilişkili iki yeni ve de novo patojenik varyasyon tespit edilmiştir. Gerçek zamanlı qPZR sonuçları ise bir başka hastada SLC2A1 geninin bir kopya kaybıla

Corresponding author/iletişim kurulacak yazar: sibel.ugur@istanbul.edu.tr

Submitted/Başvuru: 19.08.2019 • Revision Requested/Revizyon Talebi: 18.09.2019 •

Last Revision Received/Son Revizyon: 04.10.2019 • Accepted/Kabul: 10.10.2019 • Published Online/Online Yayın: 21.10.2019

(C) Telif Hakkı $2020 \mathrm{~J}$ Ist Faculty Med - Makale metnine jmed.istanbul.edu.tr web sayfasından ulaşılabilir.

(C) Copyright 2020 by J Ist Faculty Med - Available online at jmed.istanbul.edu.tr 
patible with one copy loss of SLC2A1 gene in another patient. All variations identified herein are likely to have caused null alleles and resulted in GLUT1-DS through haplo insufficiency.

Disscussion: In this study we used a series of molecular genetic approaches in order to identify all possible variations in SLC2A1 that may be associated with GLUT1-DS. This collective effort facilitated diagnosis in 3 patients.

Keywords: Glucose transporter-1 deficiency syndrome (GLUT1DS), SLC2A1, de novo variations, CNV analysis, SNP array uyumlu bulunmuştur. Tespit edilen 3 varyasyonun da SLC2A1 geninin bir allelinin fonksiyonunu tamamen ortadan kaldırarak haployetersizlik mekanizması ile hastalığa yol açtığı öngörülmüştür.

Tartışma: Bu çalışma ile pek çok farklı moleküler genetik teknik ve analizler kullanılarak GLUT1-ES hastalığında gen seviyesindeki olası tüm değişikliklerin belirlenmesi hedeflenmiş; klinik tanıya katkı sağlanmıştır.

Anahtar Kelimeler: GLUT1 Eksikliği Sendromu, SLC2A1, de novo varyasyon, CNV analizi, SNP dizileme

\section{INTRODUCTION}

GLUT1 deficiency syndrome (GLUT1-DS) is caused by heterozygous pathogenic variations of the SLC2A1 gene. SLC2A1 encodes GLUT1 protein, which acts as the primary glucose transporter along the blood-brain barrier. SLC2A1 gene is located on chromosome 1p34.2 and its largest transcript consists of 10 coding exons (1).

Lack or absence of GLUT1 protein leads to insufficient glucose levels for cerebral metabolism (1). Classical GLUT1 encephalopathy is characterized by infantile-onset seizures, developmental disability, complex motor disorders, and variable microcephaly. Although SLC2A1 variations are known to cause GLUT1-DS, there is still need for determination of proper phenotype-genotype correlations. Most patients carry heterozygous de novo mutations in the SLC2A1 gene. In familial cases, autosomal dominant inheritance is observed with full penetrance and autosomal recessive transition has rarely been reported (2). In clinical practice, the clinically available distinctive biomarker for GLUT1-DS is a low concentration of glucose in cerebrospinal fluid (CSF) $(<50 \mathrm{mg} / \mathrm{dl}$ or CSF-to-blood glucose ratio $<0.45$ ). Early diagnosis is critical for an effective etiological therapy $(3,4)$.

In this study we set out to identify possible pathogenic variations associated with GLUT1-DS in the SLC2A1 gene in 12 patients. Various molecular techniques including Sanger sequencing, SNP array analysis and real-time quantitative PCR ( $\mathrm{qPCR}$ ) were used throughout this process. The scientific importance of this study is to contribute to the discussion of diagnosis genetic causes of rare neurological diseases like GLUT1 deficiency syndrome and to determine the possible phenotype-genotype correlations.

\section{MATERIALS AND METHODS}

A cohort of 12 individuals with clinically suspected GLUT1-D Shave were recruited to the study by the Pediatric Neurology department at Kocaeli University's Medical Faculty (Table 1). DNA was isolated from peripheral

Table 1: Review of clinical findings in the study cohort.

\begin{tabular}{|c|c|c|c|c|c|}
\hline $\begin{array}{l}\text { Patient } \\
\text { Number }\end{array}$ & Sex & $\begin{array}{l}\text { Age at } \\
\text { diagnosis }\end{array}$ & $\begin{array}{l}\text { CSF glucose } \\
\text { concentration }\end{array}$ & $\begin{array}{l}\text { Parental } \\
\text { Cons. }\end{array}$ & Clinical phenotype \\
\hline E11-169 & $\mathrm{F}$ & $9 y$ & $31 \mathrm{mg} / \mathrm{ml}$ & Yes & $\begin{array}{l}\text { Microcephaly, dyskinetic movement disorder, } \\
\text { ataxia, mental retardation, epilepsy }\end{array}$ \\
\hline E13-83 & $\mathrm{F}$ & $17 y$ & $35 \mathrm{mg} / \mathrm{ml}$ & No & $\begin{array}{c}\text { Dyskinetic movement disorder, mental } \\
\text { retardation }\end{array}$ \\
\hline E15-16 & F & $1 \mathrm{y}$ & $48 \mathrm{mg} / \mathrm{ml}$ & No & $\begin{array}{l}\text { Mental retardation and early onset childhood } \\
\text { absence epilepsy }\end{array}$ \\
\hline E15-19 & F & $1 \mathrm{y}$ & $28 \mathrm{mg} / \mathrm{ml}$ & No & $\begin{array}{l}\text { Acquired microcephaly, dystonia, epilepsy, } \\
\text { psycho-motor retardation }\end{array}$ \\
\hline E15-30 & F & $5 y$ & $55 \mathrm{mg} / \mathrm{ml}$ & No & Early onset childhood absence epilepsy \\
\hline E15-34 & F & $10 y$ & $35 \mathrm{mg} / \mathrm{ml}$ & No & Early onset childhood absence epilepsy \\
\hline E15-40 & $\mathrm{F}$ & $5 y$ & $32 \mathrm{mg} / \mathrm{ml}$ & No & Early onset childhood absence epilepsy \\
\hline E15-47 & $\mathrm{F}$ & $7 y$ & $53 \mathrm{mg} / \mathrm{ml}$ & No & Early onset childhood absence epilepsy \\
\hline E16-16 & M & $6 y$ & $<20 \mathrm{mg} / \mathrm{ml}$ & No & Early onset childhood absence epilepsy \\
\hline E16-24 & $\mathrm{F}$ & $10 y$ & $<20 \mathrm{mg} / \mathrm{ml}$ & No & Early onset childhood absence epilepsy \\
\hline E17-20 & $\mathrm{F}$ & $13 y$ & $<20 \mathrm{mg} / \mathrm{ml}$ & No & Early onset childhood absence epilepsy \\
\hline E17-79 & $\mathrm{F}$ & $8.5 \mathrm{y}$ & $52 \mathrm{mg} / \mathrm{ml}$ & No & Early onset childhood absence epilepsy \\
\hline
\end{tabular}

CSF: cerebrospinal fluid; Cons.: Consanginity; F: Female; M:Male; Y: year 
blood of all patients and their family members whenever required. The DNA was first analyzed for sequence variations via Sanger sequencing and then subjected to trio SNP array genotyping only for trios with de novo variants. Real time GPCR method was additionally used for detecting any possible copy number changes that would be missed by Sanger sequencing. The study protocol was approved by Istanbul University, Istanbul Faculty of Medicine, Clinical Ethics Committee (2017/493; 12/05/2017).

\section{Genomic DNA isolation}

Peripheral blood samples were obtained in EDTA tubes and DNA was isolated using Qiagene maxi and/or mini kits as suggested. Also, $2.5 \mathrm{ml}$ of peripheral blood samples of patient E11-169 and her parents were collected in PAXgene Blood RNA Tubes and RNA was isolated using PAXgene Blood RNA Kit according to the manufacturer's instructions.

\section{Screening SLC2A1 for sequence variations}

All coding exons and neighbouring intronic regions in SLC2A1 gene had been amplified using 10 primer pairs designed for this study (Table 2). A touch down PCR (TD$P C R$ ) protocol was utilized for this purpose, which can increase specificity, sensitivity and yield, without the need for struggle optimizations and/or the redesigning of primers $(5,6)$. Each amplicon was Sanger sequenced and analyzed for sequence variations using CLC Workbench (8). Variants identified were then annotated with ENSEMBL Variant Effector Predictor Tool (VEP) for detecting the consequence of these variants on current transcript versions, retrieving up-to-date population frequency data and predicting the possible impact of amino acid substitutions on the structure and function of GLUT1 protein via PolyPhen and SIFT (https://www.ensembl.org/info/docs/ tools/vep/index.html). Splicing consequence of splice region variants were analyzed through 'Human Splicing Finder (HSF)' (http://www.umd.be/HSF/). For variations with potential pathogenic effect, familial segregation analysis was performed. All variations were annotated using the only consensus codes database transcript of SLC2A1, namely ENST00000426263.8 (NM_006516.3) as a reference.

\section{Parental confirmation by SNP array}

According to the American College of Medical Genetics (ACMG) Standards Guidelines published in 2015 (8), it is necessary to show parental relatedness with the proband for the confirmation of de novo variants. We performed SNP array genotyping using Illumina Human Cyto SNP-12

Table 2: Primer sequences to amplify 10 SLC2A1 fragments and exons covered by these fragments. Some amplicons were deigned as overlapping fragments.

\begin{tabular}{|c|c|c|c|c|}
\hline Fragment & Exons involved & Fragment length & $\begin{array}{l}\text { Fragment GC } \\
\text { content }\end{array}$ & Primer sequences \\
\hline Fr1 & ex 1 & $484 \mathrm{bp}$ & $74 \%$ & $\begin{array}{c}\text { GCCGGGGTCCTATAAACGCTAC } \\
\text { CGCTAGATCCGAAGCCCATC }\end{array}$ \\
\hline Fr2 & ex 2 & $535 b p$ & $54 \%$ & $\begin{array}{l}\text { AATGAGACCCCCAAGAATCC } \\
\text { CCAGAAAACTGGCTGGAGAG }\end{array}$ \\
\hline Fr3 & ex 3-4 & $558 \mathrm{bp}$ & $60 \%$ & $\begin{array}{l}\text { GGAAAAGGAAGACTGGGTCC } \\
\text { ACATACATGGGCACGAAGC }\end{array}$ \\
\hline Fr4 & ex $4 b$ & $535 b p$ & $65 \%$ & $\begin{array}{l}\text { ACTGGGCAAGTCCTTTGAG } \\
\text { GTGTCCAGCACAGAGAATGG }\end{array}$ \\
\hline Fr5 & ex 5-6 & $466 \mathrm{bp}$ & $71 \%$ & $\begin{array}{l}\text { CTGAAGCAGCAGCTGACACAAAG } \\
\text { GGAACAGCTCCAGGATGGTGAC }\end{array}$ \\
\hline Fr6 & ex 6-7 & $561 \mathrm{bp}$ & $58 \%$ & $\begin{array}{l}\text { TGAGCCACCCTCACCTTCC } \\
\text { TGGCATACACAGGCTGCTGC }\end{array}$ \\
\hline $\mathrm{Fr} 7$ & ex 7-8 & $609 \mathrm{bp}$ & $68 \%$ & $\begin{array}{l}\text { TTTCCCTTTAGACCCCAAGC } \\
\text { TATGAAGCCCAGGCAAACTC }\end{array}$ \\
\hline Fr8 & ex 8 & $442 \mathrm{bp}$ & $70 \%$ & $\begin{array}{l}\text { CTCTGCCCACAGCTGTTTGTG } \\
\text { GGGGTTGCTGTGAAGATGAATTG }\end{array}$ \\
\hline Fr9 & ex 9 & $359 \mathrm{bp}$ & $54 \%$ & $\begin{array}{l}\text { GGATCCATCACAACCCAGTC } \\
\text { TTCCTCCTCAGCATGATTCC }\end{array}$ \\
\hline Fr10 & ex 10 & $415 b p$ & $56 \%$ & $\begin{array}{l}\text { TCCAAAGTCCTACAGCCAGG } \\
\text { CTTCTGGACATCATTGCTGG }\end{array}$ \\
\hline
\end{tabular}


Bead Chip kit in two parent offspring trios. The data was exported from Genome Studio platform and analyzed using an in-house approach, in which only 'informative SNPs (iSNP)' were selected for each trio. For autosomal SNPs, iSNPs are described as SNPs that are alternatively homozygous in each parent. For iSNPs the child is an obligate heterozygous. As an example if we choose all SNPs with 'AA' genotype in the father and 'BB' genotype in the mother, the offspring should essentially be 'AB'. A significant degree of heterozygosity for the offspring in the trio for iSNPs will assess biological relatedness (9).

\section{Real-Time Quantitative Polymerase Chain Reaction (qPCR) approach}

In order to detect heterozygous copy number variations that may be missed by Sanger sequencing approach, we utilized real time qPCR approach using Roche Light Cycler 480 with SYBR Green I Master mix in 7 patients for over 9 SLC2A1 fragments. Herein, we aimed to map $\mathrm{CNV}$ s at the level of exonic resolution. Delta-delta Ct approach was used for data analysis using PCBP3 (Poly RC Binding Protein 3) gene as a reference. For this approach, primer pairs presented on Table 2 were used except for fragments 1, 6 and 7 . For these regions new primer pairs were designed. Nevertheless, fragment 1 could not be optimized for qPCR probably due to a relatively high GC content. Therefore, QPCR was performed for 9 fragments. New primer pairs for fragments 6 and 7 are as follows: Fr6F:ATCAACCGCAACGAGGAG,Fr6R:ACCATGCACACTTGACCAGA, Fr7F:CCCACATCCACTGCTACAGA and Fr7R:TAGTGCCCTTCTGAACCCAC.

\section{Gene expression level analysis}

Patient E11-169 and her parents were tested using mRNA expression analysis of the SLC2A1 gene to investigate any effects on the mRNA levels. For each subject, $1 \mu \mathrm{g}$ total RNA was reverse transcribed using First Strand cDNA Synthesis Kit (Fermentas) according to the manufacturer's instructions. Reverse transcription quantitative polymerase chain reaction (RT-qPCR) assay was performed triplicate using Roche Light Cycler 480 with SYBR Green I Master mix and primers located on different exons (forward primer for Fr4 and reverse primer for Fr6 as indicated in Table 2). Delta-delta Ct approach was used for data analysis using $A B L$ gene as a reference. Statistical significance was tested using one-way ANOVA.

***Reasons for choosing $A B L$ and PCBP3 as reference genes; stability, no change in the tissues or cells under investigation, these genes have the closest base length to the target gene. The reason for including the $A B L$ gene as a second reference was that it is more compatible and optimized for the mRNA sequence step than PCBP3 gene.

\section{RESULTS}

\section{Interpretation of sequence variants in SLC2A1}

Eight different single nucleotide variations were identified in 7 patients with a suspected phenotype of GLUT1-DS. Two of them (NM_006516.3: c.680-1G>C and NM_006516.3: c.542delG) were assessed to be associated with the GLUT-1 deficiency syndrome as they were found to be novel and de novo (Figure 1; Table 3). Trio SNP analysis was performed for families of E11-169 and
A

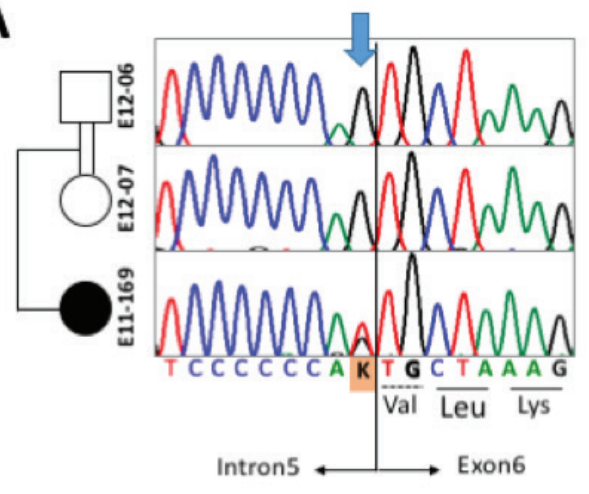

B

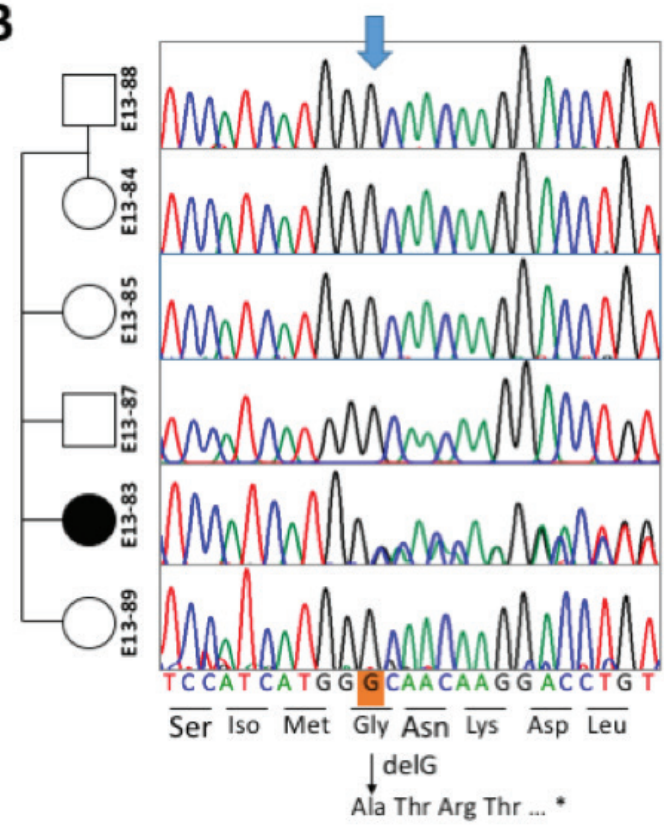

Figure 1: Segregation analysis of (a) NM_006516.3: c.680-1G>T and (b) NM_006516.3:c.542delG in the relevant families indicate a de novo pattern for the variations. K: ambiguity code for $\mathrm{G}$ or $\mathrm{T}$. 
Table 3: SLC2A1 variants identified through Sanger sequencing

\begin{tabular}{|c|c|c|c|c|c|c|c|c|}
\hline Patient ID & Variant ID & Seg. & c.DNA & Protein & MAF & Variant type & Exon & Intron \\
\hline E11-169 & Novel & de novo & c. $680-1 \mathrm{G}>\mathrm{T}$ & - & - & splice_acceptor & - & $5 / 9$ \\
\hline E13-83 & Novel & de novo & c.542delG & p.(Gly181Alafs*10) & - & frameshift & $5 / 10$ & \\
\hline E17-79 & rs11537640 & NP & c. $-197 A>C$ & - & $0.23(\mathrm{G})$ & 5_prime_UTR & $1 / 10$ & \\
\hline $\begin{array}{l}\text { E15-40, } \\
\text { E17-20, } \\
\text { E17-79 }\end{array}$ & rs1385129 & NP & c. $45 \mathrm{C}>\mathrm{T}$ & p.Ala15= & $0.24(\mathrm{~A})$ & synonymous & $2 / 10$ & \\
\hline E17-79 & rs76672402 & NP & c. $312 C>T$ & p.Phe104= & $<0.01(\mathrm{~A})$ & synonymous & $4 / 10$ & \\
\hline E17-79 & rs755559487 & NP & c. $384 C>T$ & p.lle128= & $<0.01(A)$ & synonymous & $4 / 10$ & \\
\hline $\begin{array}{l}\text { E15-30, } \\
\text { E15-47, } \\
\text { E17-20, } \\
\text { E17-79 }\end{array}$ & rs11537641 & NP & c. $399 \mathrm{C}>\mathrm{T}$ & p.Cys133= & $0.14(A)$ & synonymous & $4 / 10$ & \\
\hline $\begin{array}{l}\text { E15-30, } \\
\text { E15-47, } \\
\text { E17-20, } \\
\text { E17-79 }\end{array}$ & rs2229682 & NP & c. $588 \mathrm{G}>\mathrm{A}$ & p.Pro196= & $0.12(\mathrm{~T})$ & synonymous & $5 / 10$ & \\
\hline
\end{tabular}

NP: not performed; Seg: Segregation

E13-83 as the de novo status of the variants gives strong support for the pathogenic status if both maternity and paternity can be confirmed (8). Accordingly, iSNP analysis in both the trios of E11-169 and E13-83 resulted in $99.9 \%$ correlation for 11,385 and 16,015 iSNPs, respectively.

The de novo variant identified in E11-169 (NM_006516.3: c.680-1G>T; hg38: chr1:42,929,781C>A) is a novel splice region variant. At the same locus, another splice variant (CS057229; NM_006516.3: c.680-1G >C; hg38: chr1:42,929,781C>G) previously associated with GLUT1DS, can be interpreted as new evidence in favor of the novel variant identified herein (10). HSF analysis for both alterations (NM_006516.3: c.680-1G > T;C) revealed alteration of the wild type acceptor site, so it is possible that both variants are affecting splicing. The other novel and de novo variant in E13-83 is a single base deletion resulting in a frameshifting effect on translation (NM_006516.3:c.542delG; p.(Gly181Alafs*10); hg38:chr1:42,930,010delC). For both variations, protein truncation can be speculated, but it is likely that both alleles have a null effect possibly due to translation dependent nonsense-mediated decay. This effect well cor-

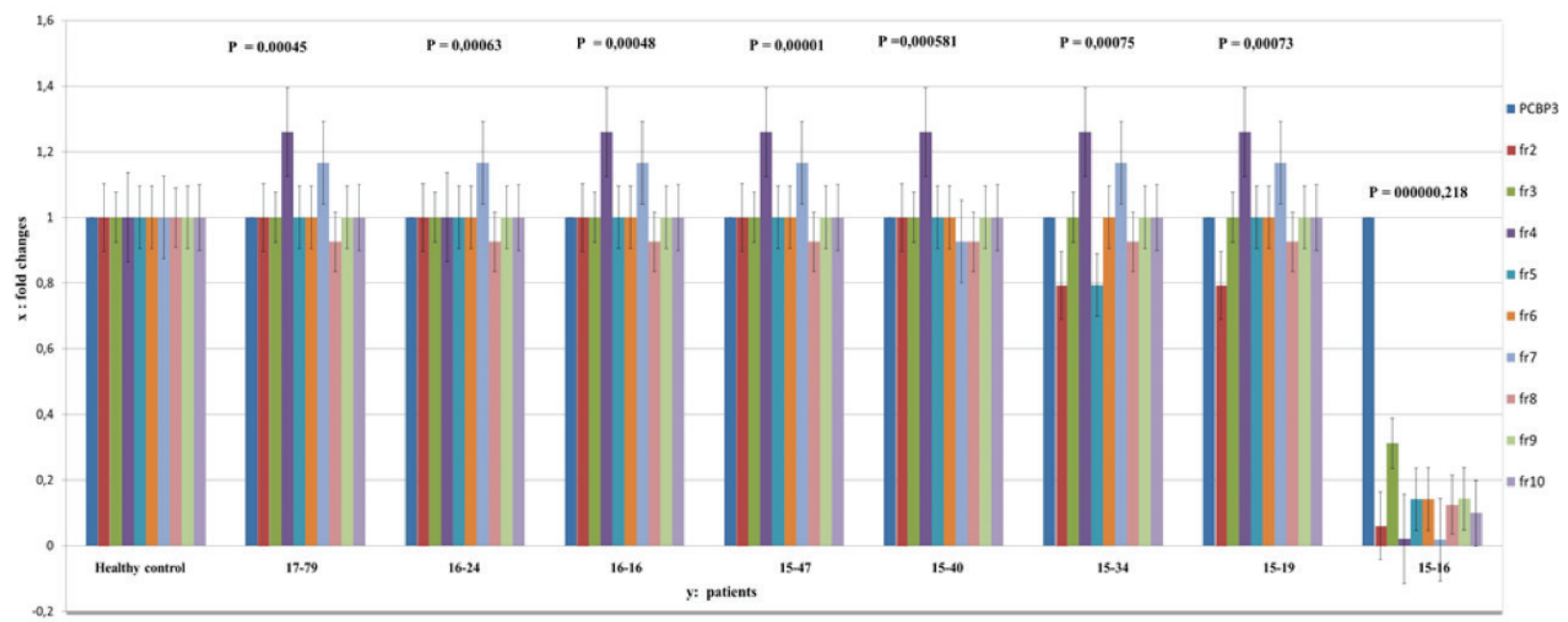

Figure 2: Graphical representation showing the comparison of the fold changes of each fragment for each patient. $P$ values and fold changes were controlled three times. ( $x$ : fold changes $y$ : patients SLC2A1: target gene, PCBP3: reference gene, control: a pool of six (three women-three men) unaffected individuals, fr: fragment). 
relates with the haplo insufficiency of pathogenic variations in development of GLUT1-DS.

\section{Interpretation of CNVs in SLC2A1}

After identifying two novel pathogenic variations, 7 available patients out of 10 were analyzed for CNV events throughout the SLC2A1 gene, using a real time qPCR approach. The result showed that only one patient (E15-16) was found to have a decreased CNV value in all SLC2A1 fragments analyzed (Figure 2). The possible loss of the allele carrying the SLC2A1 gene is again compatible with a null effect, which may result in GLUT1-DS phenotype through haplo insufficiency.

\section{Interpretation of SLC2A1 gene expression}

SLC2A1 mRNA level analysis for E11-169 and her family showed reduced expression for the index patient compared to her parents. RT-qPCR measurements indicated statistically significant decrease in the SLC2A1 gene expression compared to non-carrier healthy parents $(p=0,0002)$. Triplicate mRNA measurements revealed a mean of $49 \%$ decrease in the transcript level for the affected patient (Figure 3). Possible mechanism for complete degradation of the mutated allele can be explained by non-sense mediated decay mechanism.

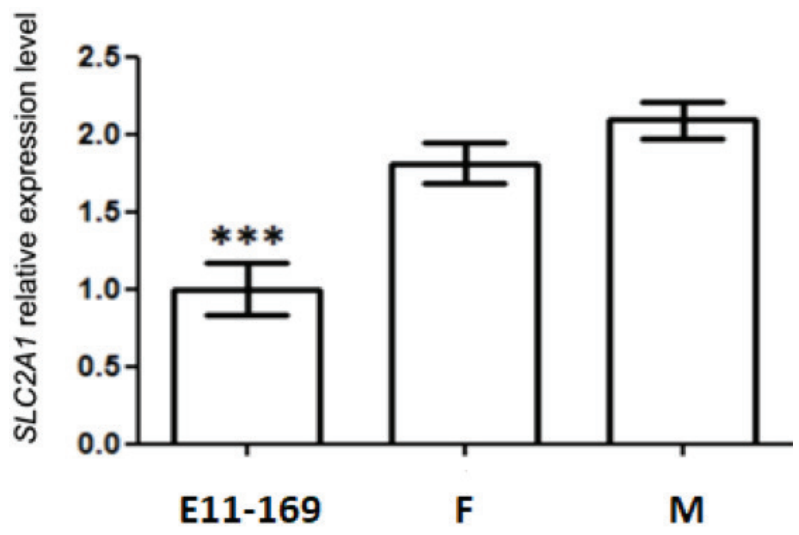

Figure 3: Triplicate mRNA measurements revealed a mean of $49 \%$ decrease in the transcript level for affected patient (E11-169) and her family (F: father, M: mother) (p:0,0003657).

\section{DISCUSSION}

In this study, we carried out screening of SLC2A1 gene by means of Sanger sequencing and CNV analysis in order to detect novel variations associated with GLUT1-DS. This approach from clinics to genetics acts as a model facilitating the correct diagnosis of this disorder. Clinical diagnosis assisted with correct genetic diagnosis is the first step for the development of possible treatment options. In this case, patients diagnosed with GLUT1-DS can be good candidates for a ketogenic diet, optimal antiepileptic treatment and other supportive therapies (11).
In this study, we have identified 3 potentially pathogenic variants using Sanger sequencing and quantitative analysis of SLC2A1 coding region. All these 3 variations (frameshift, splice region and gene copy loss) are loss of function alleles and accordingly they lead to null alleles and exert their effect on the GLUT1-DS phenotype through haploinsufficiency.

On the other hand, negative cases of SLC2A1 may be due to another unknown genetic defect, reversible transient glucose transport disorder or even other unidentified causes such as infectious, traumatic, certain antiepileptic drugs (phenobarbital, valproate sodium) (12).

Increased blood glucose levels due to a variety of causes may also reduce CSF / blood glucose ratio and cause misdiagnosis. For example, as a result of the study conducted by Leen et al., only $41 \%$ of 132 people had a variation (13). By way of another example, in the study by Vuillaumier-Barrot et al., the atypical AHC case was associated with a false mutation in SLC2A1, indicating clinical overlap between the two pathologies (14).

Screening of other GLUT members (GLUT 2/3/4/5) associated with GLUT1 and / or functional regions of SLC16A1, SLC16A3, SLC16A7 and SLC16A8 genes in which MCT1, MCT2, MCT3 and MCT4 proteins are encoded may be suggested for further molecular testing for SLC2A1 negative GLUT1DS cases.

Ethics Committee Approval: Ethics committee approval was received for this study from the Istanbul University, Istanbul Faculty of Medicine Ethics Committee.

Informed Consent: Written consent was obtained from the participants.

Peer Review: Externally peer-reviewed.

Author Contributions: Conception/Design of Study- Y.K., I.K.; Data Acquisition- Ö.Ö.; Data Analysis/Interpretation- B.K, N.B.; Drafting Manuscript- S.A.U.I.; Critical Revision of ManuscriptB.K., U.Ö.; Final Approval and Accountability- C.Ö.G., B.K., I.K., Ö.Ö., Y.K., N.B., U.Ö., S.A.U.I.

Conflict of Interest: Authors declared no conflict of interest.

Financial Disclosure: This work was supported by the grant of Scientific Research Projects Coordination Unit of Istanbul University (Project No: TYL-2017-26212).

Etik Komite Onayı: Bu çalışma için etik komite onayı İstanbul Üniversitesi İstanbul Tıp Fakültesi Etik Kurulundan alınmıştır.

Bilgilendirilmiş Onam: Katılımcılardan bilgilendirilmiş onam alınmıştır. 


\section{Hakem Değerlendirmesi: Dış bağımsız.}

Yazar Katkıları: Çalışma Konsepti/Tasarım- Y.K., i.K.; Veri Toplama- Ö.Ö.; Veri Analizi/Yorumlama- B.K, N.B.; Yazı TaslağıS.A.U.i.; İçeriğin Eleştirel İncelemesi- B.K., U.Ö.; Son Onay ve Sorumluluk- C.Ö.G., B.K., i.K., Ö.Ö., Y.K., N.B., U.Ö., S.A.U.I.

Çıkar Çatışması: Yazarlar çıkar çatışması beyan etmemişlerdir.

Finansal Destek: Bu çalışma İstanbul Üniversitesi Bilimsel Araştırma Projeleri Koordinasyon Birimi hibesi ile desteklenmiştir (Proje No: TYL-2017-26212).

\section{REFERENCES}

1. Feuk L, Carson AR, Schere SW. Structural variation in the human genome. Nat Rev Genet 2006;7(2):85-97. [CrossRef]

2. Klepper J, Scheffer H, Elsaid MF, Kamsteeg EJ, Leferink M, Ben-Omran T. Autosomal Recessive Inheritance of GLUT1 Deficiency. Neuropediatrics 2009;40(5):207-10. [CrossRef]

3. Cappuccio G, Pinelli M, Alagia M, Donti T, Day-Salvatore DL, Veggiotii P, De Giorgis V, et.al. Biochemical phenotyping unravels novel metabolic abnormalities and potential biomarkers associated with treatment of GLUT1 deficiency with ketogenic diet. PLoS ONE 2017;12(9):e0184022. [CrossRef]

4. Verrotti A, D'Egidio C, Agostinelli S, Gobbi G. Glut deficiency: when to suspect and how to diagnose? Eur J Paediatr Neurol 2012;16(1):3-9. [CrossRef]

5. Korbie DJ, Mattick JS. Touchdown PCR for increased specificity and sensitivity in PCR amplification. Nat Protoc 2008;3(9):1452-6. [CrossRef]

6. Bustina S., Huggett J. qPCR primer design revisited. Biomol Detect Quantif 2017;(14):19-28. [CrossRef]
7. Sun K, Yuen YP, Wang H, Sun H. Online Diagnosis System: A webserver for analysis of Sanger sequencing-based genetic testing data. Methods 2014;(69):230-6. [CrossRef]

8. Richards S, Aziz N, Bale S, Bick D, Das S, Foster JG, et. al. Standards and guidelines for the interpretation of sequence variants: a joint consensus recommendation of the American College of Medical Genetics and Genomics and the Association for Molecular Pathology. Genet Med 2015;17(5):405-24. [CrossRef]

9. Aylin Uğur S. Kopya Sayısı Değişikliklerinin SNP Array ile Tespiti. Turkiye Klinikleri J Pediatr Sci 2016;12(4):54-9.

10. Klepper J, Scheffer H, Leiendecker B, Gertsen E, Binder $S$, Leferink $M$, et. al. Seizure control and acceptance of the ketogenic diet in GLUT1 deficiency syndrome: a 2- to 5-year follow-up of 15 children enrolled prospectively. Neuropediatrics 2005;36:302-8. [CrossRef]

11. Klepper J, Leiendecker B. GLUT1 deficiency syndrome-2007 update. Dev Med Child Neuro 2007;49:707-16. [CrossRef]

12. Klepper J, De Vivo DC, Webb DW, Klinge L, Voit T. Reversible infantile hypoglycorrhachia: possible transient disturbance in glucose transport? Pediatr Neurol 2003;29(4):321-5. [CrossRef]

13. Leen WG, Klepper J, Verbeek MM, Leferink M, Hofste T, van Engelen BG, et al. Glucose transporter-1 deficiency syndrome: the expanding clinical and genetic spectrum of a treatable disorder. Brain 2010;133(Pt 3):655-70. [CrossRef]

14. Barrot VS, Panagiotakaki E, Bizec LC, El baba C, The ENRAhs for SME Consortium, Fontaine B, et. al. Absence of mutation in SLC2A1 Gene in a Cohort of Patients with Alternating Hemiplegia of Childhood (AHC). Neuropediatrics 2010;41:267-69. [CrossRef] 